\title{
IMRT for Nasal Tumors - Local Control and Cosmetic Outcome
}

Stefan Janssen ${ }^{1}$, Christoph Glanzmann ${ }^{1}$, David Holzmann ${ }^{2}$ and Gabriela Studer ${ }^{1^{\star}}$

${ }^{1}$ Department of Radiation Oncology, University Hospital Zurich, Zurich, Switzerland

${ }^{2}$ Department of Otorhinolaryngology, Head and Neck Surgery, University Hospital Zurich, Zurich, Switzerland

"Corresponding author: Studer G, Department of Radiation Oncology, University Hospital Zurich, Zurich, Switzerland, Tel: +1 44255 29 30; E-mail: gabriela.studer@usz.ch

Received date: Feb 28, 2014, Accepted date: April 04, 2014, Publication date: April 15, 2014

Copyright: ( 2014 Janssen S, et al. This is an open-access article distributed under the terms of the Creative Commons Attribution License, which permits unrestricted use, distribution, and reproduction in any medium, provided the original author and source are credited.

\section{Abstract}

Background: To evaluate local control and cosmetic outcome in patients with cancer in the nasal cavity/vestibule treated with intensity-modulated radiotherapy (IMRT).

Methods: From 06/2008 - 11/2012 15 consecutive patients presenting nasal cavity $(n=5)$, ala of the nose ( $n=5)$ or nasal vestibule tumors $(n=5)$ were treated in our institution either postoperatively $(n=8)$ or as definitive treatment $(n=7)$.

Results: Mean/median follow-up (FU) was 30/22 months (range 17-62). Two patients suffered from a local relapse. As a salvage therapy an ablatio nasi was carried out in curative intention in both patients. Thereafter no failure was reported. Local control rate, ultimate local control and overall survival after 2 years were $87 \%, 100 \%$ and $100 \%$, respectively. None of the patients developed grade II or higher late sequels. Cosmetic outcome after RT was very satisfying so far.

Conclusion: IMRT for nasal tumors is effective and well tolerated. Radical surgical procedures can be saved for curative salvage treatment.

Keywords: Nasal tumors; IMRT; SIB-IMRT; Definitive radiotherapy; Cosmetic outcome

\section{Introduction}

Tumors of the nasal cavity or of the nasal vestibule are rare [1]. Optimal treatment depends on tumor size, tumor expansion and nodal status and includes definitive or postoperative radiotherapy, or surgery alone. Surgical removal often implies complex reconstruction which may end in disfiguring results and consecutively essential impairment of quality of life. Radiation therapy (RT) can be carried out as external beam or brachytherapy, with good local control rates of $67-92 \%$ after 5 years [2-6].

Recently, few single center study groups presented retrospective data on treating patients with sinunasal cancer with intensity modulated radiotherapy (IMRT). They revealed excellent local control rates with minimized toxicity [7-12]. In those series only a minority of included patients were diagnosed with nasal cavity or nasal vestibule tumors. Cosmetic outcomes were therefore not evaluated.

The goal of the present study was to show effectiveness of IMRT in a single center series of a homogeneous patient collective with nasal tumors in terms of local control and cosmetic outcome.

\section{Patients and Methods}

From $06 / 2008$ to $11 / 201215$ consecutive patients presenting with histologically proven squamous cell cancer (SCC, $\mathrm{n}=13$ ) or adenocarcinoma $(n=2)$ were treated in our institution with IMRT either postoperatively after tumor excision $(\mathrm{n}=8)$ or as definitive treatment $(\mathrm{n}=7)$.

Patient and treatment parameters are summarized in Table 1. One patient had ipsilateral lymph node metastases (N1). In this case a neck dissection was carried out prior to IMRT.

The dose was normalized to the mean dose in planning target volume (PTV) 1. For intensity optimization, the prescribed dose encompassed at least $95 \%$ of the PTV. Simultaneously integrated boost (SIB) was used delivering two-three different dose levels in the same treatment session.

Target volumes were delineated as follows: GTV included the gross extent of primary disease, taking clinical and radiological findings into account; PTV1 was defined by adding 10-15 $\mathrm{mm}$ margin to the GTV, dependent on the GTV proximity to critical structures eye, optical nerve); PTV2 covered areas considered at high risk for potential microscopic disease. No elective lymph node irradiation was carried out. Mean GTV volume was $12.4 \mathrm{ccm}$ (range: $2.9-27.9 \mathrm{ccm}$ ).

\begin{tabular}{|l|l|}
\hline Mean age (years) & $\mathbf{5 8}$ (range: $\mathbf{2 8 - 7 8 )}$ \\
\hline Gender & \\
\hline Male & $12(80 \%)$ \\
\hline Female & $3(20 \%)$ \\
\hline RT sequence & \\
\hline Postoperative IMRT & $8(54 \%)$ \\
\hline
\end{tabular}


Page 2 of 7

\begin{tabular}{|l|l|}
\hline Definitive IMRT & $7(46 \%)$ \\
\hline Histology & \\
\hline SCC & $13(87 \%)$ \\
\hline adenocarcinoma & $2(13 \%)$ \\
\hline Location & \\
\hline nasal cavity & $5(33.3 \%)$ \\
\hline vestibule & $5(33.3 \%)$ \\
\hline ala of the nose & $5(33.3 \%)$ \\
\hline $\begin{array}{l}\text { RT doses } \\
\text { (5 fractions/week) }\end{array}$ & \\
\hline $35 \times 2=70$ Gy & $6(40 \%)$ \\
\hline $34 \times 2=68 G y$ & $2(13 \%)$ \\
\hline $33 \times 2=66$ Gy & $5(33 \%)$ \\
\hline $32 \times 2=64$ Gy & $1(7 \%)$ \\
\hline $31 \times 2=62 G y$ & $1(7 \%)$ \\
\hline TN-status & $2(13 \%)$ \\
\hline T1 & $10(66 \%)$ \\
\hline T2 & $1(7 \%)$ \\
\hline T3 & $2(13 \%)$ \\
\hline T4 & 0 \\
\hline N1 & $0(54 \%)$ \\
\hline N2 & 0 \\
\hline N3 & \\
\hline N4 & \\
\hline Cisplatin or cetuximab concomitant \\
\hline
\end{tabular}

Regular FU visits were carried out in our joint clinic at the Department of Otorhinolaryngology, Head and Neck Surgery. Institutional standards for patient assessment included physical examination approximately every 2 months in the first year of followup, every three months in the second to third year and every 6 months in the fourth to fifth year. Last FU and grading of toxicity (CTCAE grading system) was performed personally or by phone calling (SJ or GS in 08-09/13).

\section{Systemic Therapy}

Systemic therapy preferably consisted of cisplatin $\left(40 \mathrm{mg} / \mathrm{m}^{2}\right.$ weekly) and was switched to cetuximab in case of cisplatin related adverse effects (cetuximab loading dose: $400 \mathrm{mg} / \mathrm{m}^{2}$ followed by weekly applications of $250 \mathrm{mg} / \mathrm{m}^{2}$ referring to Bonner et al. [13]). For patients with contraindications against cisplatin, cetuximab was favored primarily. The indication for systemic therapy was based on tumor stage, resection status, age and Karnofsky performance score. 8 patients presenting with $\mathrm{T} 4$ tumors, N1 or R1 resection received systemic therapy. Cisplatin was started in 6 patients, a switch to cetuximab was carried out in four patients after $2(n=3)$ and $4(n=1)$ courses due to tinnitus $(n=3)$ or rising levels of creatinine $(n=1)$. In two patients with contraindications against cisplatin, cetuximab was preferred as first choice.

\section{Statistics}

Statistical calculation was performed using the statistic program implemented in Stat View (Version 4.5; SAS Institute, Cary, NC).

\section{Results}

\section{Outcome}

Mean/median FU was 30/22 months (range 17-62). Median local control, ultimate local control and overall survival after 2 years was $87 \%$ (Figure 1), 100\% and 100\%, respectively. Two patients developed a loco-regional relapse after 6 and 10 months, respectively. One of those patients was treated with definitive RT; one had an excision before RT. Ablatio nasi was carried out in both cases as successful salvage therapy revealing no recurrence up to now 7 and 26 months later, respectively.

Mean dose to the left and right lacrimal glands was 2.9 Gy (range: 0.5-9.3 Gy), and 2.6 Gy (range: 0.5-7 Gy). The maximal lens dose was 6.6 Gy (range: 3.7-11.6 Gy) and 6.5 Gy (range: 1.9-13.3 Gy) on the right and left side, respectively. Dose to the lacrimal sac/proximal nasolacrimal duct was estimated and summed up to a mean value of 25 Gy (range: 3-58) on the right side and 29 Gy (range: $2-56$ ) on the left.

To ensure sufficient dose delivery to the skin close to GTVs, bolus material $(0.5 .1 \mathrm{~cm}$ thickness) was used in all patients (Figure 2-7). Nasal tamponade was used in all patients, to reduce/avoid build up effect. Irradiation was delivered with three to seven coplanar beam angles by a 6-MV dynamic MLC system (Varian Medical Systems, Palo Alto, CA) using sliding window technique, or using volumetric modulated arc technique (VMAT, since 04/2010). Patients were immobilized from head to shoulders using a commercially available thermoplastic mask in supine position.

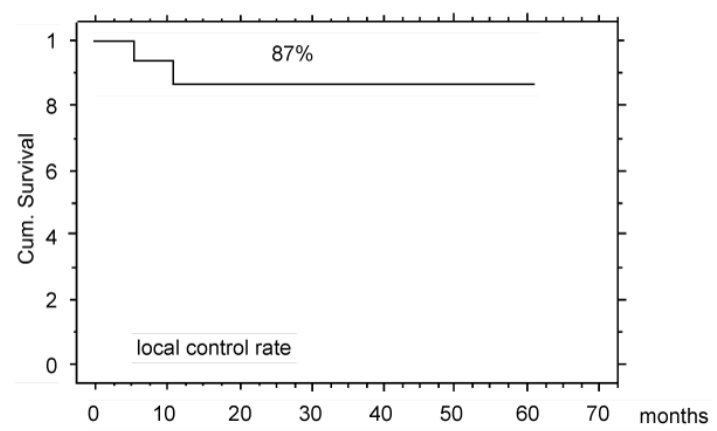

Figure 1: Kaplan Meier curve of local control rate. 
Citation: Janssen S, Glanzmann C, Holzmann D, Studer G (2014) IMRT for Nasal Tumors - Local Control and Cosmetic Outcome. J Nucl Med

Page 3 of 7

\section{Late term effects}

No grade II or higher late sequels were seen during the FU time so far. 12/13 organ preserved tumor free patients suffered from a mild to moderate dryness of the nasal mucosa which was tolerable under symptomatic therapy (Table 3 ). One patient described a repetitive grade 2 epistaxis, one patient a grade 1 epistaxis. In consequence to the low doses to the lacrimal glands and lenses mentioned in the methods section no severe late adverse effect concerning the lacrimal glands or vision is expected. No nasolacrimal stenosis occurred in any patient.

\section{Cosmetic results}

At the time of last visit each patient was asked to evaluate the cosmetic results of RT using a scale from 1-5 in which 1 would stand for no satisfaction with respect to cosmetic outcome and 5 for high satisfaction with the cosmetic outcome comparable with status before initial diagnosis and treatment. Patients rated cosmetic outcome either as excellent (grade 5,9/13) or as good (grade 4, 4/13). Table 2 summarizes the results for each patient. In Figures 2-7 exemplary photographs demonstrate objective outcome related to the isodose plans of patients who underwent definitive IMRT.

\begin{tabular}{|c|c|c|c|c|c|c|}
\hline & RT sequence & T stage & Tumor site & RT dose & $\begin{array}{l}\text { Patients' satisfaction } \\
\text { with cosmesis * }\end{array}$ & Late sequels \\
\hline 1 & definitive & 2 & ala & 70 & ablatio & dry nasal mucosa grade I \\
\hline 2 & definitive & 2 & vestibule & 70 & 5 & none \\
\hline 3 & definitive & 2 & nasal cavity & 70 & 5 & $\begin{array}{l}\text { Intermittent epistaxis, } \\
\text { dry nasal mucosa grade I }\end{array}$ \\
\hline 4 & definitive & 4 & vestibule & 68 & 5 & dry nasal mucosa grade I \\
\hline 5 & definitive & 2 & nasal cavity & 68 & 5 & dry nasal mucosa grade I \\
\hline 6 & definitive & 2 & ala & 70 & 5 & dry nasal mucosa grade I \\
\hline 7 & definitive & 2 & nasal cavity & 70 & 4 & dry nasal mucosa grade I \\
\hline 8 & postoperative & 4 & vestibule & 66 & ablatio & dry nasal mucosa grade I \\
\hline 9 & postoperative & 1 & ala & 66 & 5 & dry nasal mucosa grade I \\
\hline 10 & postoperative & 2 & nasal cavity & 66 & 5 & dry nasal mucosa grade I \\
\hline 11 & postoperative & 3 & vestibule & 62 & 5 & $\begin{array}{l}\text { dry nasal mucosa grade I, intermittent } \\
\text { epistaxis }\end{array}$ \\
\hline 12 & postoperative & 2 & ala & 66 & 4 & $\begin{array}{l}\text { slightly olfactory impairment, dry } \\
\text { nasal mucosa grade I }\end{array}$ \\
\hline 13 & postoperative & 2 & ala & 66 & 4 & dry nasal mucosa grade I \\
\hline 14 & postoperative & 2 & nasal cavity & 64 & 5 & dry nasal mucosa grade I \\
\hline 15 & postoperative & 1 & vestibule & 70 & 4 & dry nasal mucosa grade I \\
\hline
\end{tabular}

Table 2: Summary of cosmetic outcome and late sequels for each patient (CTCAE grade 1=asymptomatic mucosal crusting, grade 2: interfering with airflow, grade 3: significant nasal obstruction) ${ }^{\star}$ Cosmetic outcome in self-assessment using a 5 point scale (" 1 " $=$ poor cosmetic outcome, " 5 "=very satisfying).

\begin{tabular}{|c|c|c|c|c|c|c|c|c|c|}
\hline & $\begin{array}{l}\text { Patients } \\
\text { (n) }\end{array}$ & $\begin{array}{l}\text { Nasal } \\
\text { tumors (\%) }\end{array}$ & $\begin{array}{ll}\begin{array}{l}\text { Definitive } \\
(\%)\end{array} & \text { RT } \\
\end{array}$ & RT technique & $\begin{array}{l}\text { RT dose (Gy) } \\
\text { (Dose/fraction) }\end{array}$ & $\begin{array}{l}\text { CTx } \\
(\%)\end{array}$ & LC (\%) & OS (\%) & $\begin{array}{l}\text { Cosmetic } \\
\text { results }\end{array}$ \\
\hline $\begin{array}{l}\text { Katz et al. } \\
{[14]}\end{array}$ & 78 & 62 & 60 & $\begin{array}{ll}\text { Anterior } & \text { and } \\
\text { lateral fields } & \end{array}$ & $\begin{array}{l}68 \text { ( } 1.8 \text { or } 1.2 \text { twice } \\
\text { daily) }\end{array}$ & 1 & 60 (5yrs) & 50 (5yrs) & n.a. \\
\hline $\begin{array}{l}\text { Langendijk } \\
\text { et al. [4] }\end{array}$ & 56 & 100 & 100 & $\begin{array}{ll}\text { Opposed lateral } \\
6 \mathrm{MV} \text { fields } \\
\text { boost }\end{array}$ & $67.5(2.5)$ & 0 & 80 (2yrs) & 66 (2yrs) & n.a. \\
\hline $\begin{array}{l}\text { Levendag } \\
\text { et al. [6] }\end{array}$ & 64 & 100 & 78 & BT & 44 (3 twice daily) & 0 & 92 (5yrs) & 59 (5yrs) & $\begin{array}{l}65 \% \text { excellent } \\
\text { or good results } \\
(n=23)\end{array}$ \\
\hline $\begin{array}{l}\text { Wallace et } \\
\text { al. [2] }\end{array}$ & 71 & 100 & 89 & $\begin{array}{lr}\text { Anterior } & \text { field } \\
\text { elektrons } \\
6 \mathrm{MV}, & \text { and } \\
\end{array}$ & $65-75$ & 3 & 87 (5yrs) & $76(5 y r s)$ & $\begin{array}{l}\text { n.a.for def. } \\
\text { treatment, poor } \\
\text { for } 6 \text { patients }\end{array}$ \\
\hline
\end{tabular}


Citation: Janssen S, Glanzmann C, Holzmann D, Studer G (2014) IMRT for Nasal Tumors - Local Control and Cosmetic Outcome. J Nucl Med Radiat Ther 5: 170. doi:10.4172/2155-9619.1000170

Page 4 of 7

\begin{tabular}{|l|l|l|l|l|l|l|l|l|l|}
\hline & & & & BT & & & $\begin{array}{l}\text { and good for 2 } \\
\text { patients treated } \\
\text { with surgery and } \\
\text { RT }\end{array}$ \\
\hline $\begin{array}{l}\text { Agger et al. } \\
{[14]}\end{array}$ & 174 & 100 & 69 & $\begin{array}{l}\text { Opposed lateral } \\
\text { fields 250KV or } \\
\text { MV }\end{array}$ & & & & & \\
$62-66(2)$ & & 0 & 67 (5yrs) & 50 (5yrs) & n.a. \\
\hline Total & 443 & 92 & 79 & & & 1 & 77 & 60 & \\
\hline
\end{tabular}

Table 3: Summary of studies on conventionally treated patients with nasal cancer published in the IMRT era (not treated with IMRT). BT: Brachytherapy; n.a.: not assessed

\section{Systemic therapy}

No late sequels were observed concerning systemic therapy.

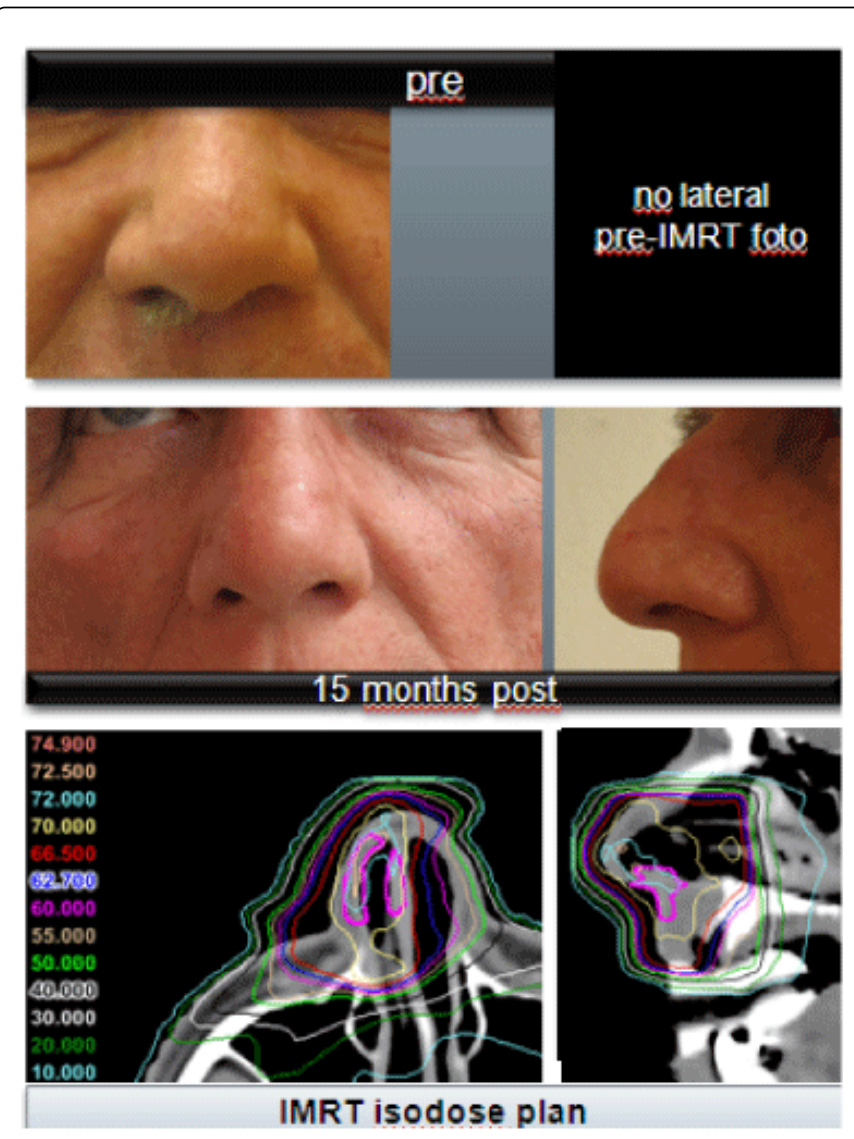

Figure 2: 55 year old patient, vestibule nasi tumor T2N0, GTV volume: $2.9 \mathrm{ccm}, 70 \mathrm{~Gy}$.

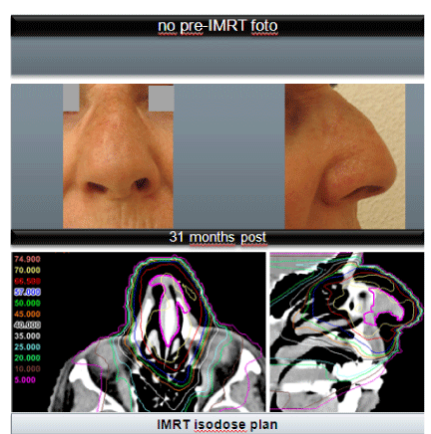

Figure 3: 56 year old patient, cavum nasi tumor T2N1, GTV volume: $13.2 \mathrm{ccm}, 70 \mathrm{~Gy}$.

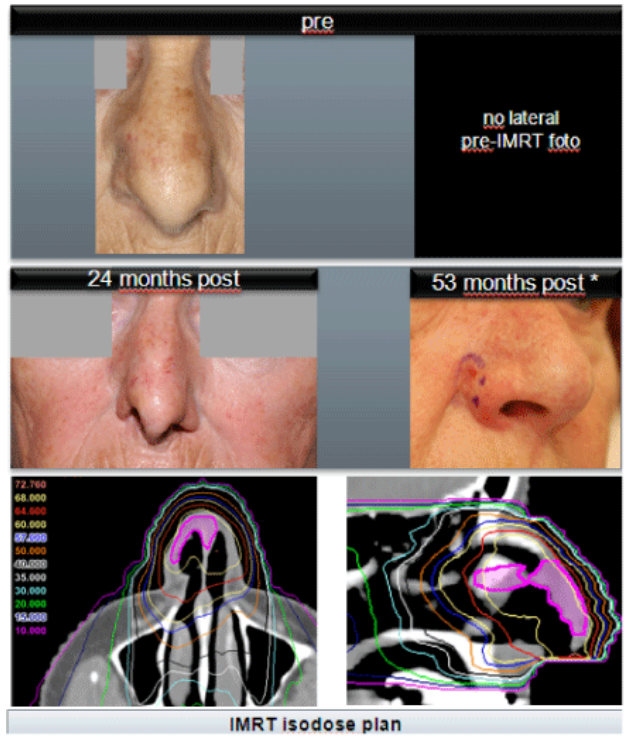

Figure 4: 66 year old patient, vestibule nasi tumor T4N0, GTV volume: $6.8 \mathrm{ccm}, 68 \mathrm{~Gy}$ 
Citation: Janssen S, Glanzmann C, Holzmann D, Studer G (2014) IMRT for Nasal Tumors - Local Control and Cosmetic Outcome. J Nucl Med

Page 5 of 7
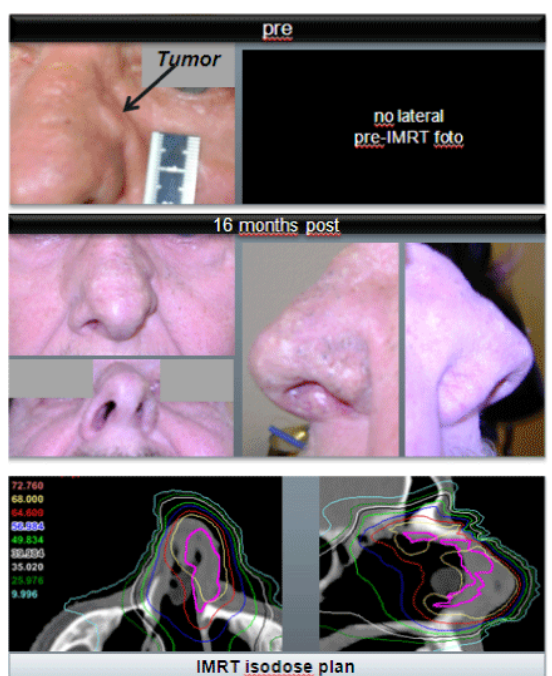

Figure 5: 67 year old patient, cavum nasi tumor T2N0, GTV volume: $9.5 \mathrm{ccm}, 68 \mathrm{G}$ y
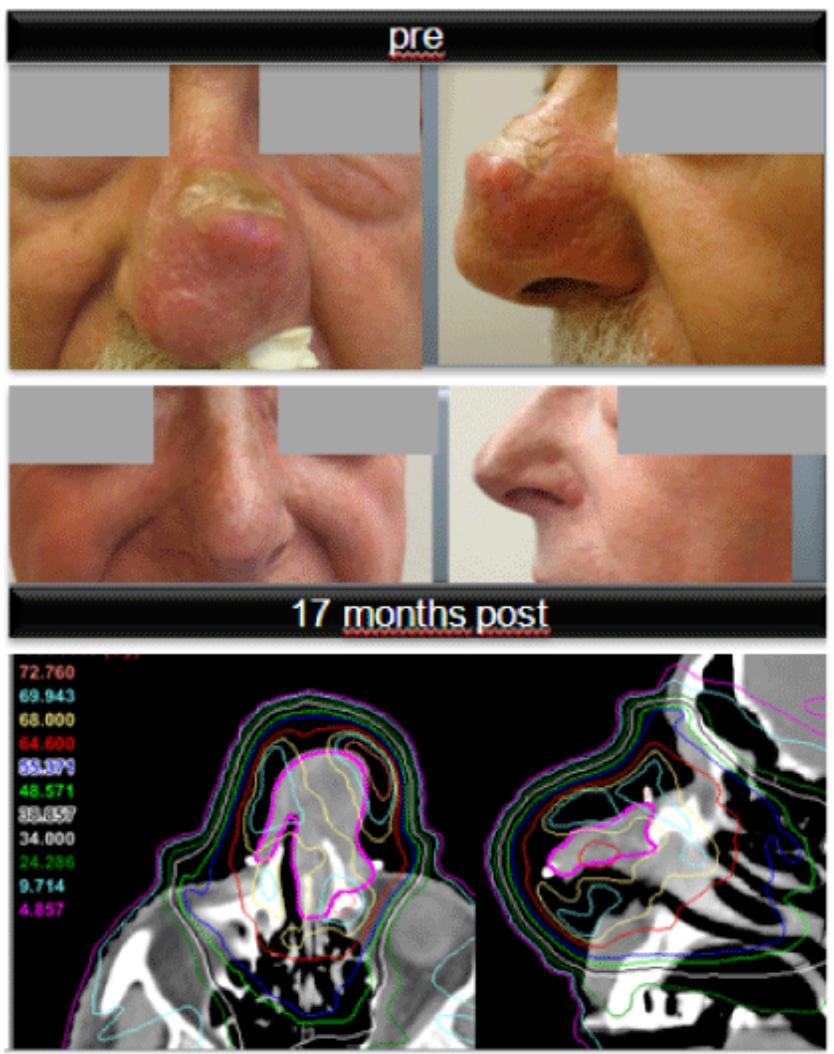

IMRT isodose plan

Figure 6: 69 year old patient, ala nasi tumor T2N0, GTV volume: $27.9 \mathrm{ccm}, 70 \mathrm{~Gy}$.

\section{Discussion}

We evaluated clinical outcome and early cosmetic results in a patient group presenting with exclusively nasal tumors treated with IMRT.

In historic series on cohorts treating nasal vestibule tumors with conventional RT or brachytherapy, local control and overall survival rates range from $67 \%$ to $92 \%$ and $50 \%$ to $90 \%$, respectively $[2,4,6,14]$. The largest series of the DAHANCA study group including 174 patients with nasal vestibule cancer reports a local control rate and an overall survival rate of $67 \%$ and $50 \%$ at 5 years, respectively [14] (Table 3 ). In the latter series RT was delivered in opposed lateral fields (KV or MV) or with an anterior electron field +/- brachytherapy boost. Doses range from $54 \mathrm{~Gy}$ in $3 \mathrm{~Gy}$ single doses to $62-69 \mathrm{~Gy}$ in 2 Gy or $2.5 \mathrm{~Gy}$ doses $[2,4,14]$. Langendijk et al. observed rhinorrhoe in $45 \%$, nasal dryness in $39 \%$ and epistaxis in $15 \%$ of the patients as late toxicity (4). Radiation induced necrosis of the skin was seen in 3 patients. Wallace et al. showed severe late term complications requiring hospitalization and/or surgical intervention in 3 out of 8 postoperatively treated patients. $21 \%$ of patients treated with RT only experienced complications which resolved without intervention [2].

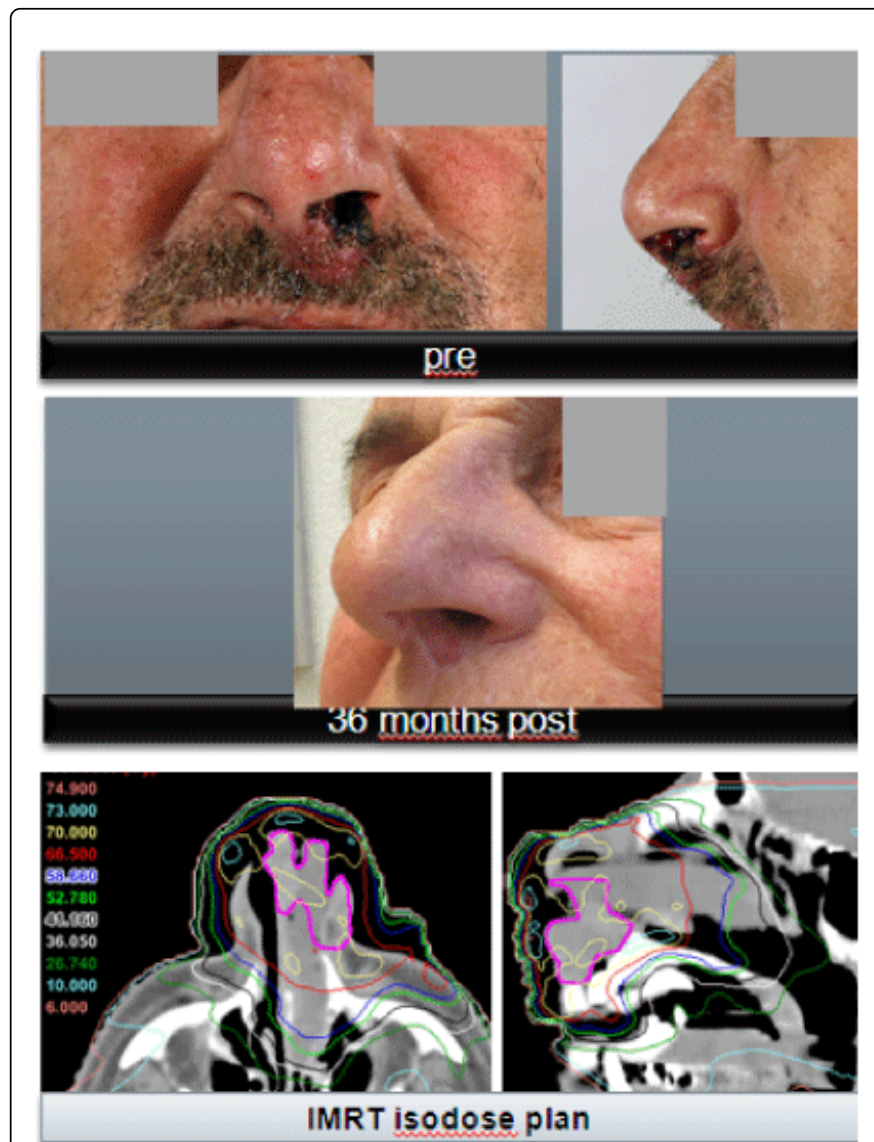

Figure 7: 78 year old patient, vestibule nasi tumor T2N0, GTV volume: $20.2 \mathrm{ccm}, 70 \mathrm{~Gy}$.

IMRT is effective to deliver high doses to target volumes while limiting the dose to adjacent critical structures [12]. We found 7 other 
Page 6 of 7

single center retrospective studies reporting comparable local control $(49-87 \%)$ and overall survival data of $45-100 \%$ at $2-5$ years with low rate of toxicity in patients with sinunasal cancer [7-12,15]. Most IMRT series did not observe any grade 3 visual impairment [8-11]. In contrast to the above mentioned series with conventional RT techniques, those IMRT series included mostly paranasal cavity tumors with different histologies ranging from SCC to esthesioneuroblastoma, adenoidcystic carcinoma and sarcomas. Only a small number of patients with nasal cavity/nasal vestibule tumors were included (Table 4). No published IMRT series evaluating patients with nasal cancer exclusively could be found.

Furthermore most of the patients were treated postoperatively. Definitive treatment was carried out in only $9 \%-21 \%$ in the collectives of Wiegner, Duprez and Madani, respectively while other reports assessed series with only postoperatively treated patients [9-11].

In contrast we had half the cases treated with definitive IMRT. Our results of local control and overall survival are comparable with the large series of conventional treated patients as well as the heterogeneous group treated with IMRT. For our small sample size, disease control was identical for postoperative and definitive IMRT. Cosmetic outcomes were not evaluated in any of the other IMRT studies. Wallace et al. treating nasal vestibule cancer patients with conventional RT only report of "poor" cosmetic results in 6 patients and "good" cosmetic results in 2 patients treated with surgery and RT [2]. Levendag et al. evaluated cosmetic outcome consequently in patients with early-stage nasal vestibule cancer treated with brachytherapy. They scored cosmetic results using a 3 point scale. $65 \%$ showed good or excellent objective results judged by an external panel [6]. We used a five point scale in order to further differentiate outcome. Furthermore, we did not assemble an external panel to evaluate cosmetic outcome; cosmetic results as presenting at last visit of the patients treated with 70Gy are shown in Figure 2. Altogether cosmetic outcome is very satisfying with only grade 4 and 5 in selfassessment standing for good and excellent outcomes.

\begin{tabular}{|c|c|c|c|c|c|c|c|c|c|}
\hline & $\begin{array}{l}\text { Patients with } \\
\text { sinunasal } \\
\text { tumors } \\
\text { (n) }\end{array}$ & Nasal tumors (\%) & $\begin{array}{l}\text { Definitive RT } \\
\text { (\%) }\end{array}$ & RT technique & $\begin{array}{l}\text { RT dose } \\
\text { (Dose/ } \\
\text { fraction) (Gy) }\end{array}$ & $\begin{array}{l}\text { CTx } \\
(\%)\end{array}$ & LC (\%) & OS (\%) & $\begin{array}{l}\text { Cosmetic } \\
\text { results }\end{array}$ \\
\hline $\begin{array}{l}\text { Combs et al. } \\
\text { [9] }\end{array}$ & 46 & $16 / 46(35)$ & 0 & IMRT & $64(2)$ & 0 & 49 (3yrs) & 90 (3yrs) & n.a. \\
\hline $\begin{array}{l}\text { Daly et al. } \\
\text { [10] }\end{array}$ & 36 & 7/36 (19) & 0 & IMRT & $70(2.12)$ & 17 & 58 (5yrs) & 45 (5yrs) & n.a. \\
\hline $\begin{array}{l}\text { Hoppe et al. } \\
\text { [15] }\end{array}$ & 85 & $24 / 85(28)$ & 0 & IMRT in $35 \%$ & $50-70(1.8-2)$ & 2 & 87 (5yrs) & 67 (5yrs) & n.a. \\
\hline $\begin{array}{l}\text { Madani et al. } \\
\text { [7] }\end{array}$ & 84 & $16 / 84(19)$ & 11 & IMRT & $70(2)$ & 0 & 71 (5yrs) & 59 (5yrs) & n.a. \\
\hline $\begin{array}{l}\text { Dirix et al. } \\
\text { [11] }\end{array}$ & 40 & $6 / 40(15)$ & 0 & IMRT & 60/66 (2) & 0 & 76 (2yrs) & 89 (2yrs) & n.a. \\
\hline $\begin{array}{l}\text { Duprez et al. } \\
\text { [8] }\end{array}$ & 130 & $31 / 130(24)$ & 22 & IMRT & $70(2)$ & 5 & 59 (5yrs) & 52 (5yrs) & n.a. \\
\hline $\begin{array}{l}\text { Wiegner et al. } \\
\text { [12] }\end{array}$ & 52 & $11 / 52(21)$ & 9 & IMRT & $66(2.2)$ & 56 & 74 (2yrs) & 66 (2yrs) & n.a. \\
\hline Present study & 15 & $15 / 15(100)$ & 47 & IMRT & & 53 & 87 (2yrs) & $100(2 \mathrm{yrs})$ & $\begin{array}{l}69 \% \text { excellent, } \\
31 \% \text { good }\end{array}$ \\
\hline Total & 488 & 126 & 11 & & & 17 & 70 & 71 & \\
\hline
\end{tabular}

Table 4: Summary of series including all sinunasal tumor sites treated with IMRT, no separate analysis of outcome in patients with nasal tumors, n.a. $=$ not assessed.

Larger studies including nasal tumors executively are mostly not applying chemotherapy $[2,4,6,14]$. IMRT studies dealing with a heterogeneous patient collective including paranasal sinus cancers were applying systemic therapy in 0 to and $17 \%[7-11,15]$. Wiegner et al. applied chemotherapy in a sub collective of patients with nasal cancer in $36 \%$ [12]. In our study collective systemic therapy was given in $54 \%$.

Even our study collective is small and the FU is short, to our knowledge this is the first study evaluating cosmetic outcomes in patients with nasal tumors treated with IMRT.

\section{Conclusion}

SIB-IMRT in patients presenting with nasal cancer is effective in terms of local control and overall survival either postoperatively after tumor excision or as definitive organ sparing IMRT. Early cosmetic outcomes were subjectively as well as objectively very satisfying. Ablatio nasi can be saved for curative salvage therapy.

\section{References}

1. Muir CS, Nectoux J (1980) Descriptive epidemiology of malignant neoplasms of nose, nasal cavities, middle ear and accessory sinuses. Clin Otolaryngol Allied Sci 5: 195-211. 
Citation: Janssen S, Glanzmann C, Holzmann D, Studer G (2014) IMRT for Nasal Tumors - Local Control and Cosmetic Outcome. J Nucl Med Radiat Ther 5: 170. doi:10.4172/2155-9619.1000170

Page 7 of 7

2. Wallace A, Morris CG, Kirwan J, Amdur RJ, Werning JW, et al. (2007) Radiotherapy for squamous cell carcinoma of the nasal vestibule. Am I Clin Oncol 30: 612-616.

3. Thorup C, Sebbesen L, Danø H, Leetmaa M, Andersen M, et al. (2010) Carcinoma of the nasal cavity and paranasal sinuses in Denmark 1995-2004. Acta Oncol 49: 389-394.

4. Langendijk JA, Poorter R, Leemans CR, de Bree R, Doornaert P, et al (2004) Radiotherapy of squamous cell carcinoma of the nasal vestibule. Int J Radiat Oncol Biol Phys 59: 1319-1325.

5. Chen AM, Daly ME, Bucci MK, Xia P, Akazawa C, et al. (2007) Carcinomas of the paranasal sinuses and nasal cavity treated with radiotherapy at a single institution over five decades: are we making improvement? Int J Radiat Oncol Biol Phys 69: 141-147.

6. Levendag PC, Nijdam WM, van Moolenburgh SE, Tan L, Noever I, et al. (2006) Interstitial radiation therapy for early-stage nasal vestibule cancer: a continuing quest for optimal tumor control and cosmesis. Int J Radiat Oncol Biol Phys 66: 160-169.

7. Madani I, Vakaet L, Bonte K, Boterberg T, De Neve W (2008) Intensitymodulated radiotherapy for cervical lymph node metastases from unknown primary cancer. Int J Radiat Oncol Biol Phys 71: 1158-1166.

8. Duprez F, Madani I, Morbée L, Bonte K, Deron P, et al. (2012) IMRT for sinonasal tumors minimizes severe late ocular toxicity and preserves disease control and survival. Int J Radiat Oncol Biol Phys 83: 252-259.

9. Combs SE, Konkel S, Schulz-Ertner D, Münter MW, Debus J, et al. (2006) Intensity modulated radiotherapy (IMRT) in patients with carcinomas of the paranasal sinuses: clinical benefit for complex shaped target volumes. Radiat Oncol 1: 23.

10. Daly ME, Chen AM, Bucci MK, El-Sayed I, Xia P, et al. (2007) Intensitymodulated radiation therapy for malignancies of the nasal cavity and paranasal sinuses. Int J Radiat Oncol Biol Phys 67: 151-157.

11. Dirix P, Vanstraelen B, Jorissen M, Vander Poorten V, Nuyts S (2010) Intensity-modulated radiotherapy for sinonasal cancer: improved outcome compared to conventional radiotherapy. Int J Radiat Oncol Biol Phys 78: 998-1004.

12. Wiegner EA, Daly ME, Murphy JD, Abelson J, Chapman $\mathrm{CH}$, et al. (2012) Intensity-modulated radiotherapy for tumors of the nasal cavity and paranasal sinuses: clinical outcomes and patterns of failure. Int J Radiat Oncol Biol Phys 83: 243-251.

13. Bonner JA, Harari PM, Giralt J, Azarnia N, Shin DM, et al. (2006) Radiotherapy plus cetuximab for squamous-cell carcinoma of the head and neck. N Engl J Med 354: 567-578.

14. Katz TS, Mendenhall WM, Morris CG, Amdur RJ, Hinerman RW, Villaret DB (2002)Malignant tumors of the nasal cavity and paranasal sinuses. Head Neck 24 : 821-829.

15. Hoppe BS, Stegman LD, Zelefsky MJ, et al.( 2007) Treatment of nasal cavity and paranasal sinus cancer with modern radiotherapy techniques in the postoperative setting--the MSKCC experience. Int J Radiat Oncol Biol Phys. 67: 691-702.
This article was originally published in a special issue, entitled: "Cancer Radiation Therapy", Edited by Xin Chen,University of Arkansas for Medical Sciences, USA 